\title{
Contiguous granular cell myoblastoma and squamous cell carcinoma in the oesophagus
}

\author{
P MANNION, RP HONAN, MD FITZGERALD, PS HASLETON \\ From the Departments of Pathology and Cardiothoracic Surgery, Regional Cardiothoracic Centre, \\ Wythenshawe Hospital, Manchester
}

It has been stated that carcinoma must never be diagnosed in the presence of granular cell myoblastoma, ${ }^{\prime}$ in view of the associated pseudoepitheliomatous hyperplasia. We submit a case with collision tumours of squamous cell carcinoma and granular cell myoblastoma in the oesophagus as a rare example.

\section{Case report}

A 68 year old woman presented with a history of two months' dysphagia and two years' intermittent indigestion and retrosternal discomfort. She had lost $9.5 \mathrm{~kg}$ in weight in four months. The patient had smoked up to 20 cigarettes a day for many years. Her past medical history was unremarkable. Barium swallow showed an irregular filling defect at the junction of the middle and lower third of the oesophagus. Oesophagoscopy confirmed a ragged lesion at $31 \mathrm{~cm}$. After biopsy, which showed a well differentiated squamous cell carcinoma, oesophagogastrectomy was performed. Three months after operation the patient had recurrent dysphagia and a subsequent biopsy showed recurrent squamous cell carcinoma but no granular cell myoblastoma.

The operation specimen comprised an $11 \mathrm{~cm}$ segment of distal oesophagus with a cuff of stomach $4 \mathrm{~cm}$ long. In the oesophagus there were two collision tumours (fig 1). One was an annular, grey, centrally ulcerated tumour $(2.8 \mathrm{~cm}$ long and $1.5 \mathrm{~cm}$ deep) and the other a yellowish grey, umbilicated, submucosal tumour $2 \mathrm{~cm}$ in length and $1 \mathrm{~cm}$ in depth. The latter was situated on the gastric side of the ulcerated tumour, directly abutting on to it.

The larger tumour was a moderately well differentiated squamous carcinoma (flg 2), in some areas arising from dysplastic surface epithelium, going through to the serosa; it affected two lymph nodes and showed venous invasion. The smaller submucosal tumour blended with the muscularis mucosae in places. It was separated from the muscularis propria by a narrow margin of unaffected submucosa. It was unencapsulated and consisted of syncytial cords and islands of large cells with finely granular eosinophilic cytoplasm and faint PAS positivity separated by a scanty fibrous stroma (fig 2 ). No mitoses were seen. The appearance of the tumour were typical of a benign granular cell myoblastoma.

Address for reprint requests: Dr PS Hasleton, Department of Pathology, Regional Cardiothoracic Centre, Wythenshawe Hospital, Manchester M23 9LT.

Accepted 12 December 1984

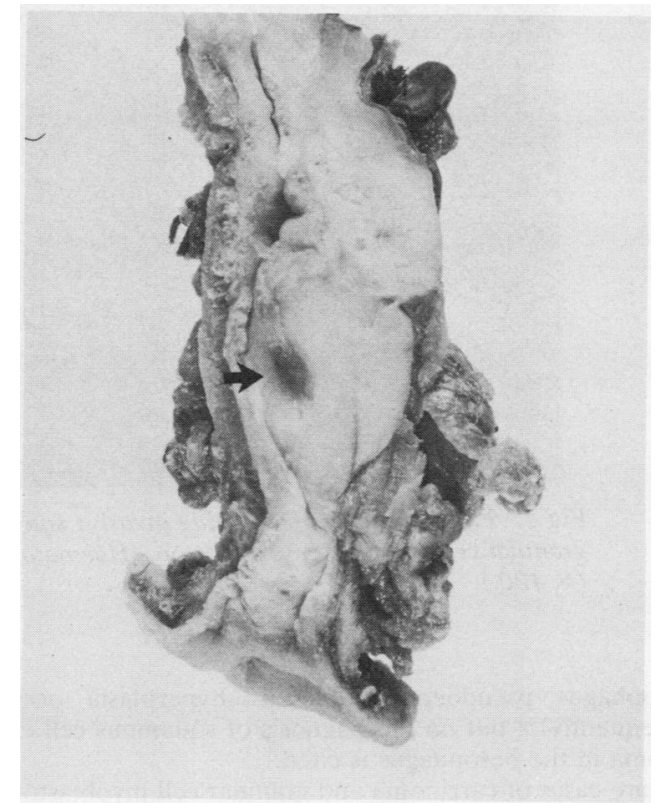

Fig 1 Macroscopic specimen showing umbilicated, fairly well defined granular cell myoblastoma (arrow) with adjacent infiltrating squamous cell carcinoma above.

In all the sections a thin fibrous septa separated the lateral border of the granular cell myoblastoma from the carcinoma. In most areas there was a distinct gap between the myoblastoma and the surface squamous epithelium. Occasional islands of dysplastic epithelium were present overlying the myoblastoma.

\section{Discussion}

The present case illustrates collision tumours with a granular cell myoblastoma occurring contiguously with an invasive squamous cell carcinoma. It has been stated ${ }^{2}$ that "a review of the world literature fails to demonstrate a case of true squamous carcinoma, as evidenced by metastasis, intimately associated with or caused by a granular cell myoblastoma." In the present case, however, there is unequivocal evidence of squamous carcinoma as shown by invasion through the serosa, lymph node metastases, venous invasion, and postoperative recurrence. In the 


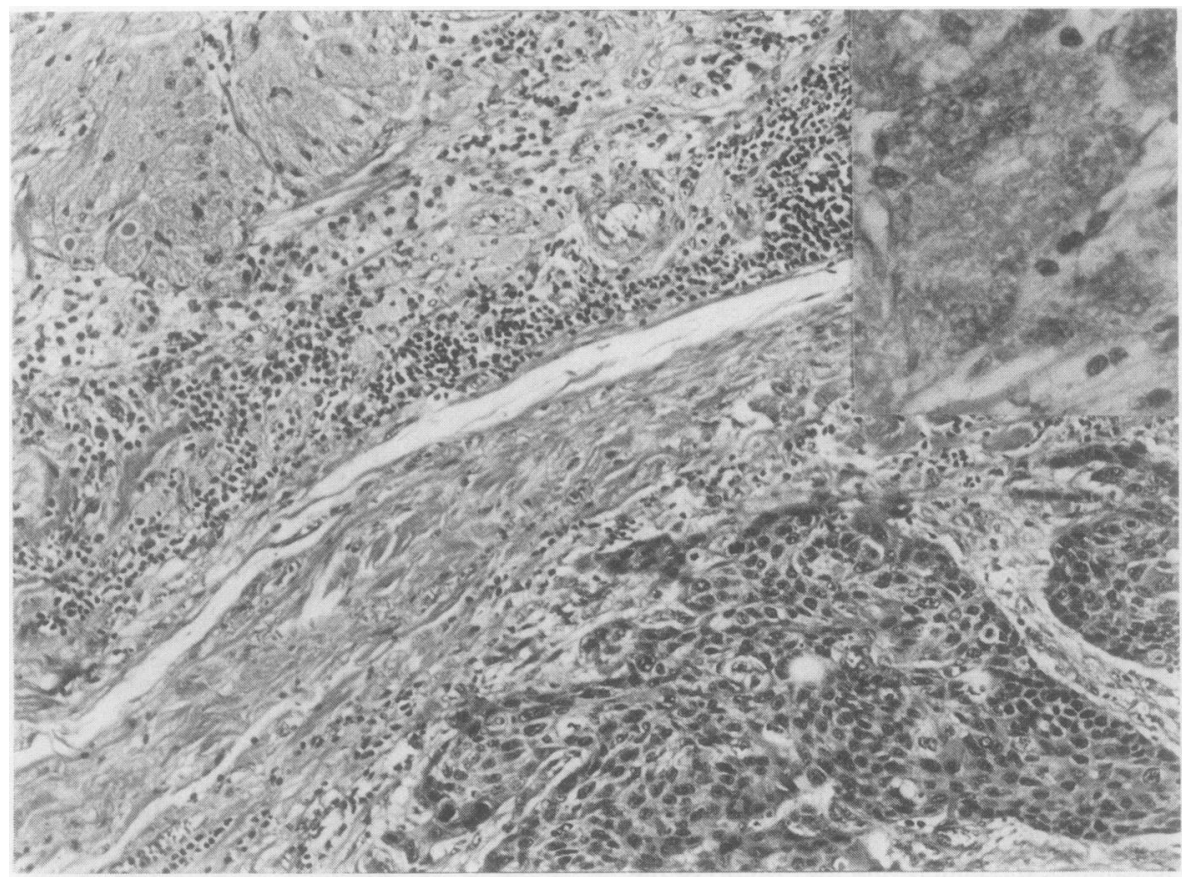

Fig 2 Photomicrograph showing invasive squamous cell carcinoma at the bottom of the picture and granular cell myoblastoma at the top. (Haematoxylin and eosin, $\times 20$.) Inset: Granular cell myoblastoma. $(\times 400$.

oesophagus pseudoepitheliomatous hyperplasia occurs infrequently ${ }^{3}$; but no misdiagnosis of squamous cell carcinoma in the oesophagus is cited.

Rare cases of carcinoma and granular cell myoblastoma in the same organ at adjacent sites have been described in the tongue, ${ }^{2}$ breast, ${ }^{5}$ vulva, ${ }^{6}$ larynx, ${ }^{78}$ lung,,$^{4-11}$ and oesophagus..$^{1213}$ In contrast to our case, in few of these is close histological contiguity of the two tumours illustrated. There are two cases of coincidental oesophageal carcinoma and granular cell myoblastoma. In the case of Domen et $a l,,^{12}$ the two tumours did not occur together. The authors suggest that irradiation given for the carcinoma may have caused the granular cell myoblastoma. The second case, ${ }^{13}$ is similar to ours, although in the illustrated resection specimen the two tumours are separated by a distinct albeit small gap. In the resection specimen the epithelium overlying the granular cell myoblastoma was unremarkable, although in the initial biopsy specimen pseudoepitheliomatous hyperplasia was noted. The myoblastoma had been present for at least 16 months before the development of the carcinoma. Johnston and Helwig ${ }^{14}$ reviewed 24 cases of oesophageal granular cell myoblastoma, of which 15 were incidental necropsy findings. In an unspecified number there was an association with oesophageal carcinoma or varices. Full pathological details of these cases were not given and we do not know whether collision tumours were present in any of them.

In our case the virtual contiguity of the two tumours raised the possibility of a causal relationship. In view of the initial biopsy specimen the possibility that the granular cell lesion represented the granular cells deposited at the site of previous trauma, ${ }^{15}$ and thought to be an entity distinct $ᄋ$ from granular cell myoblastoma, was considered. These $\underset{x}{\sim}$ collections of granular cells, similar to those in granular cell $\overline{0}$ myoblastoma, are incidental microscopic findings, usually at sites of previous surgery or trauma and often in or near $\varnothing$ smooth muscle. In our case the lesion formed a visible tumour and is unlikely to have developed over the short period between biopsy and surgery. The second hypothesis is that the granular cell myoblastoma had been present for $\frac{D}{O}$ some time and that the pseudoepitheliomatous hyperplasia overlying it had undergone malignant change. The clinical $N$ history may lend support to this idea-the two years' history of indigestion and retrosternal discomfort being due to $\mathrm{N}$ the granular cell myoblastoma while the dysphagia and $N$ weight loss were caused by the carcinoma. Histologically, $\sigma$ however, invasive carcinoma should have arisen in the epithelium directly overlying the myoblastoma. This showed only occasional islands of dysplastic epithelium whereas dysplastic epithelium merging into invasive car-? cinoma was seen in relation to the squamous cell car- $T$ cinoma. The appearances were not those of pseudoepitheliomatous hyperplasia, which was most marked over the central part of the granular cell myoblas-市 toma and showed no dysplasia. We concluded that the tumours were collision tumours that had arisen contigu- 
ously by pure chance. It is unlikely that a single unknown aetiological factor, acting both on the surface epithelium and on the underlying tissue, produced both tumours.

We are grateful to Mr Grant Whitehurst and the staff of the medical illustration department for the photographic work and to Mrs C Harris for typing the manuscript.

\section{References}

1 Booth JB, Osborn DA. Granular cell myoblastoma of the larynx. Acta Otolaryngol 1970; 70:279-93.

2 Colberg JE, Hubay CA. Granular cell myoblastoma-a problem in diagnosis. Surgery 1963;53:226-37.

3 Gibbons JRP, Bharucha J, Soorae AS. Granular cell tumour of the oesophagus. Am J Gastroenterol 1980;74:161-4.

4 Farrell KH, Devine KD, Harrison EG, Olsen AM. Granular cell myoblastoma of the oesophagus. Incidence and surgical treatment. Ann Otol Rhinol Laryngol 1973;82:784-9.

5 Mulcare R. Granular cell myoblastoma of the breast. Ann Surg 1968;168:262-8.

6 Lack EE, Worsham GF, Callihan MD, et al. Granular cell tumour: a clinicopathologic study of 110 patients.J Surg Oncol 1980;13:301-16.
7 Goldstein A, Thaler S, Rozycki D. Granular cell myoblastoma and carcinoma of the larynx. Arch Otolaryngol 1971;94:366-8.

8 McSwain GR, Colpitts R, Kreutner A, O'Brien PH, Spicer S. Granular cell myoblastoma. Surg Gynecol Obstet 1980; 150: 703-10.

9 Tamayo JL, Rojas MC. Granular cell myoblastoma (granular cell Schwannoma) of the right upper bronchus coexisting with a bronchogenic carcinoma. Report of first case in the literature. J Thorac Cardiovasc Surg 1971;62:268-70.

10 Rogers DR. Coincidental pulmonary granular cell Schwannoma and bronchogenic adenocarcinoma. Alaska Med 1973;15:4-5.

11 Hurwitz SS, Conlan AA, Gritzman MCD, Krut LH. Coexisting granular cell myoblastoma and squamous carcinoma of the bronchus. Thorax 1982;37:392-3.

12 Domen RE, Tang P, Harshman KV. Granular cell myoblastoma of the oesophagus after irradiation for carcinoma. South Med J 1979;72:1207-9.

13 Lehn E, Collery PS, Salas H, Pluot M, Levasseur JC. Association d'une tumeur a cellules granuleuses et d'un cancer de roesophage. J Chir (Paris) 1981;118:325-9.

14 Johnston J, Helwig EB. Granular cell tumours of the gastrointestinal tract and perianal region. A study of 74 cases. Dig Dis Sci 1981;26:807-16.

15 Sobel HJ, Marquet E. Granular cell and granular cell lesions. Path Annu 1974;9:43-79. 